Cereal Research Communications 36(4), pp. 659-667 (2008)

DOI: $10.1556 / C R C .36 .2008 .4 .15$

\title{
Changing of Flight Phenology and Ecotype Expansion of the European Corn Borer (Ostrinia nubilalis Hbn.) in Hungary
}

\author{
Part 2. Graphical Evaluation \\ S. KESZTHELYI ${ }^{1}$, J. PUSKÁS ${ }^{2}$ and L. NOWINSZKY ${ }^{2}$ \\ ${ }^{1}$ University of Kaposvár, FAS, Kaposvár, Hungary \\ ${ }^{2}$ Berzsenyi Dániel Teacher's Training College, Szombathely, Hungary
}

(Received 15 June 2007; accepted 14 July 2008)

\begin{abstract}
The studies aimed to acquire the widest possible information on the annual flight in Hungary of the European corn borer (ECB), Ostrinia nubilalis Hübner (Lepidoptera: Pyralidae). The investigations used biomathematical (Part 1) and graphical (Part 2) assay to document forthcoming changes in the individual population number.

The study was conducted in Hungary using ECB moth capture records from the Plant Protection Information System black light trap system (1991-2004). We have drawn conclusions on the appearance of annual flights and the tendency of alterations in flight direction by means of light trap results in four different areas in Hungary. We prepared and estimated the flight phenology diagrams of ECB in this part.

Assay of 224 flight phenology diagrams showed the phenomenon of flight alteration too, which characterized the cyclical change of different phenology types. We determined four well-differentiated flight types. The European corn borer (ECB) univoltine ecotype is characterized by a "bell" type and the bivoltine ecotype is characterized by "nail" type. We also ascertained two temporary types. The "plateau" type can be observed in the initial period of flight alteration, and the "valley" type in the latter stages of flight alteration.
\end{abstract}

Keywords: European corn borer, flight

\footnotetext{
* Corresponding author; E-mail: ostrinia@gmail.com
} 


\section{Introduction}

The impact of climate change on the biology and distribution of the European corn borer

The ECB develops in different generation numbers depending on its distribution territory (Ellsworth et al. 1989; Onstad and Brewer 1996). According to the annual number of generations, univoltine, bivoltine and multivoltine ecotypes have been defined (Showers et al. 1975). In Hungary, the univoltine and the bivoltine ecotypes are found. It is due to differences in the heat unit requirements of post-diapause development (Nagy 1961).

Mészáros (1969) determined the borderline between these ecotypes as being the $3200{ }^{\circ} \mathrm{C}$ isotherm. To the north from Hungary's low-mountain regions, the univoltine ecotype is prevalent, whereas to the south the bivoltine ecotype is found.

The examination of climatic factors can explain the development and distribution of ecotypes (Beck 1983; Lavenseau et al. 1985). According to Sáringer (1976) the total temperature and photoperiod are the most important factors in the generation number of a region. The function of light is irrelevant in Hungary, because the sunny hours in the Carpathian Basin are always more than 12 a day between $22^{\text {nd }}$ April and $20^{\text {th }}$ August, which may give rise to the possibility of the bivoltine ecotype appearing across the whole country.

In the case of the ECB we must distinguish between the concepts of flight and generation, because not every flight peak indicates a new generation. Whilst the generation is the period of time required to complete the life cycle of an insect, till in the case of the ECB the flight peak can be originated from protracted emergence of the generation (Nagy and Szentkirályi 1993; Nagy et al. 1997).

\section{Materials and Methods}

We examined changes in the temporal patterns of ECB moth flights by processing the data from the Hungarian light trap system [Plant Protection Information System (NIR) of the Hungarian Central Plant Protection and Soil Conservation Service].

The examination was carried out between 1991 and 2004. The choice of the period was justified by two factors. (1) Since the 1990s an ever growing number of publications have been dealing with the effects of global climate change on Hungary (Székács et al. 2005), which reflects the importance of this phenomenon, 
and (2) it is for that time interval that a more or less uniform series of ECB catching data was available from various parts of the country.

We have processed ECB light trap catches originating from 4 sites in each of four different districts of Hungary. Moths were recovered from trap daily, and the representation of catches happened on traps every fifth day. The location and the climatic features of four different districts can be seen in part 1 of the article.

We made diagrams of flight phenology for ECB caught by light traps between 1991 and 2004 for each of the four districts, and visually examined whether any regularity or cyclic similarity was evident from sequential comparison of the data series. Having evaluated 224 flight diagrams we laid down general rules concerning the flight pattern of the ECB, and the characteristics of any change occurring in it. These rules were the following: beginning-, end-, time-span of the flight, numbers of the flight peaks and feature of flight phenology.

\section{Results}

Examining the flight diagrams we found regularity and cyclicity in the change of the flight phenology during the consecutive years. The gradual change in the flight phenology of the ECB in Hungary is shown through the individual population numbers caught by the trap in village Tanakajd trap from 1991 to 2004. This place of trapping represented best the alteration of flight (Figs $1-3)$. The figures in the diagrams give a simplified picture of the change, the periodical phenology of flight.

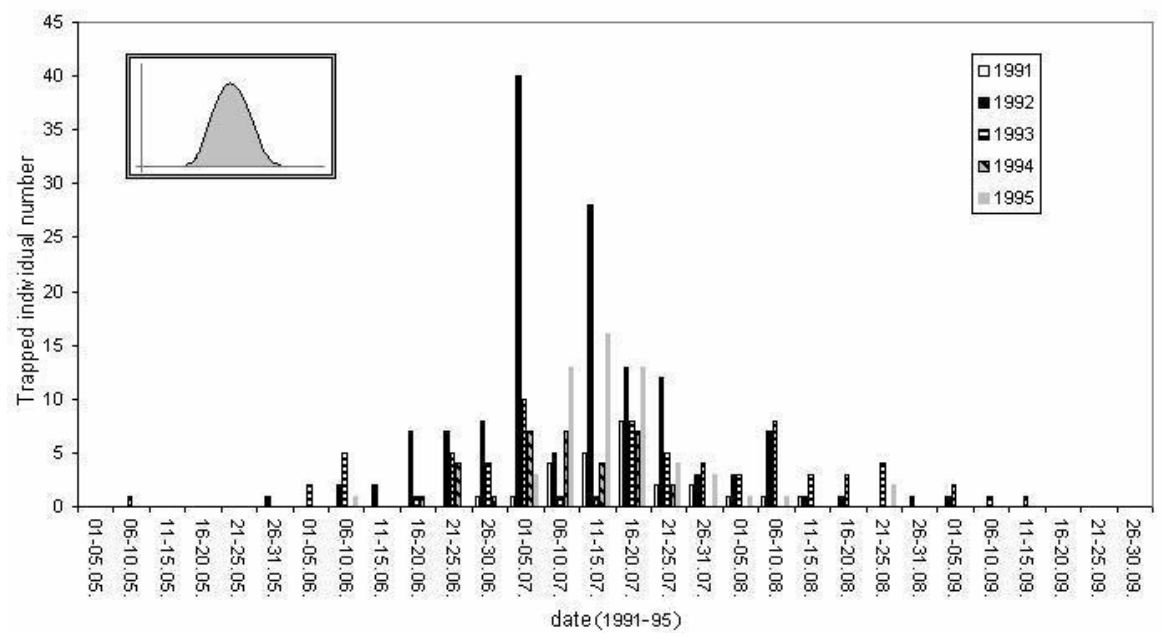

Figure 1. "Bell”-type flight of ECB (Tanakajd; Vas county; 1991-1995) 


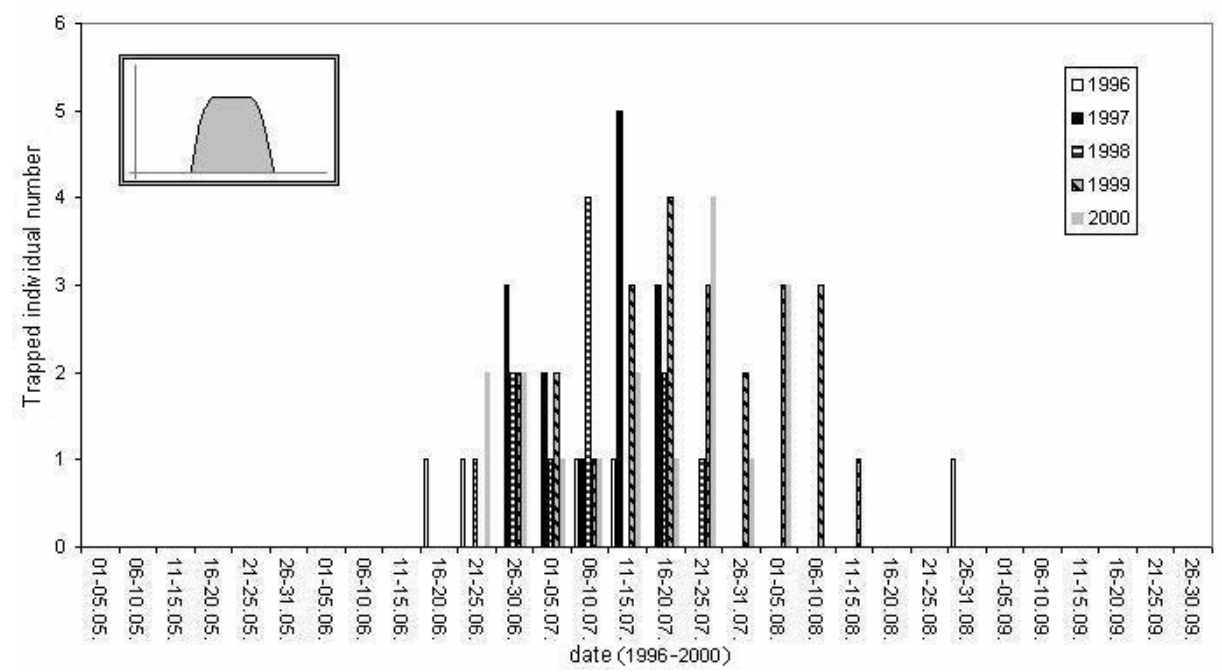

Figure 2. "Plateau"-type flight of ECB (Tanakajd; Vas county; 1996-2000)

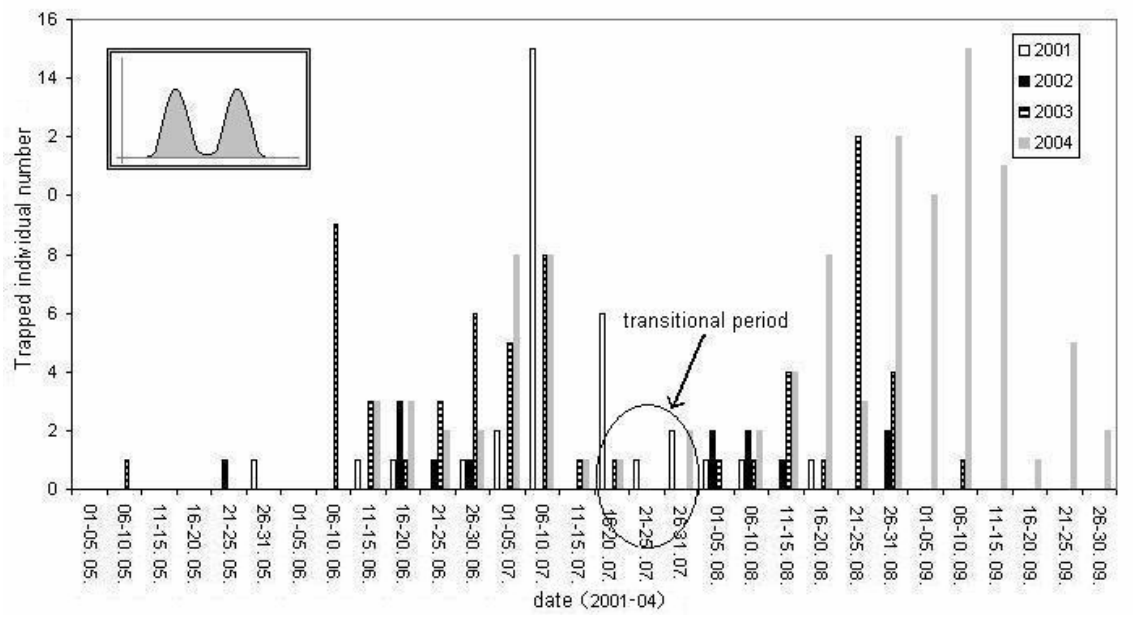

Figure 3. "Valley"-type flight of ECB (Tanakajd; Vas county; 2001-2004)

According to the figures until 2004, the pest in the mentioned area flought with one peak per year, between 1 and 15 June (Fig. 1). In the remaining part of the year this peak was not followed by further significant appearance of adults. After Gauss' theory applied to populations of normal distribution (Straub 1977) this phenological curve is called "bell" type. Since 1998 a "phenological fluctua- 
tion" of flight has been observed (Fig. 2). Although a further definite peak cannot yet be said to have appeared, the flight peak of adults occurs over a wider space of time. The pattern of flight becomes "plateau"-like.

The "phenological fluctuation" of flight is followed by a clearly observable change in the pattern of flight. Since 2002 a marked second peak has appeared in the last third of summer (Fig. 3), and the flight has two peaks separated by a valley ("valley" type) pattern of flight. The valley between the peaks can be regarded as a "transitional period", which in the case of the bivoltine ecotype preceeds the appearance of the second generation.

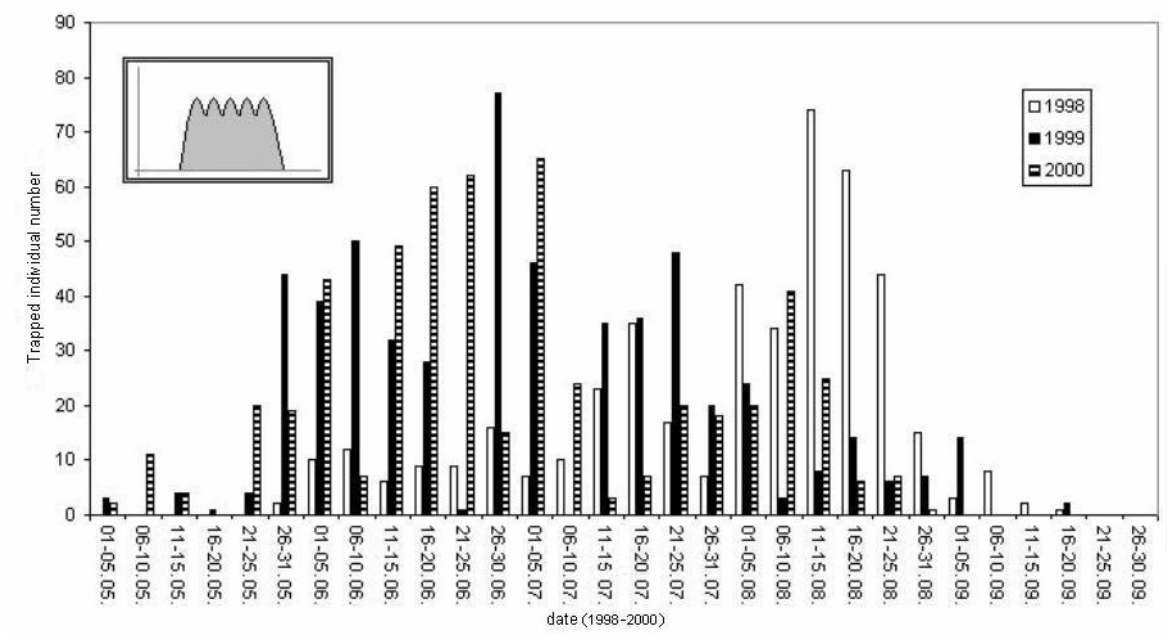

Figure 4. "Plateau"-type flight of ECB (Nemesgulács; Veszprém county; 1998-2000)

Figure 4 demonstrates the other phenological subtype of the "plateau"-like flight pattern, which appeared in Nemesgulács similarly in a short interval of time (1998-2000), preceeding the "valley"-type pattern of flight. The appearance of peaks cannot be precisely determined, their development is accidental. However, in the case of this type too, the phenomenon of eruption and crisis (collapse) of flight - to use the concepts taken from the science of gradology - is clearly outlined (Jermy 1988).

The fourth type of flight pattern is one appearing with a dominant second peak, as registered by the southeastern Hungarian and Fejér county light traps since 1997-1998; it is represented by the catching results of Székkutas (Fig. 5). Here the second flight peak is often $7-8$ times as high as the individual population number trapped at the beginning of summer in the same year. This peak generally 


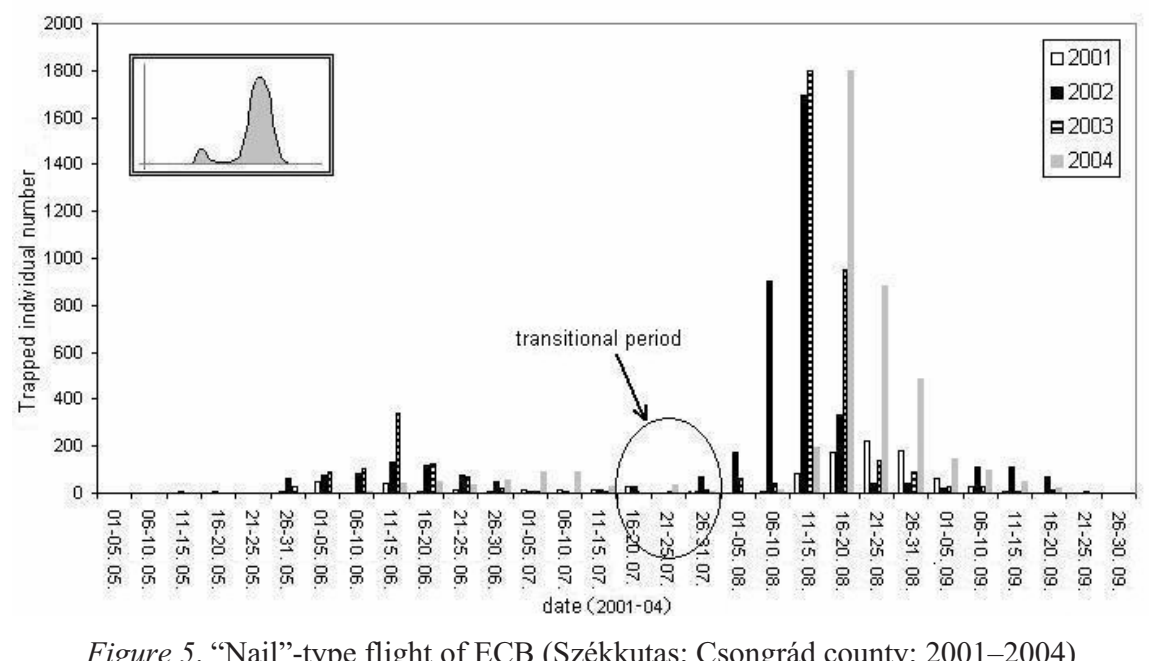

appears between 5 and 20 August. This pattern, which has a "transitional period", is called a "nail"-type flight picture, because of the sharply protruding second peak.

In the case of the "nail"- and "valley"-type flight patterns, we mentioned the concept of a "transitional period". In Figures 3 and 5, the time for the appearance of the transitional period is clearly shown. The ECB developmental degree is among $0-5 \%$ in this period. By a visual examination and mathematical averaging of the 224 flight phenology diagrams, the time space of this period was determined uniformly as 15 days. For the "valley"-type, the transitional period occurs on 10-25 of July, while for the "nail"-type it falls between 15-30 of July. The individual population number of ECB trapped in this time interval is roughly $0-12 \%$ of the number of adults trapped outside of it.

Table 1 contains the number of individuals trapped during the transitional periods compared to the total number of individuals trapped. The trend indicated by the data from each district also reflects the occurrence of the above-mentioned change of flight in Hungary. The "transitional period" connecting the two peaks and preparing the second peak can in fact be adapted more correctly to the "valley"- and "nail"-type patterns of flight, as reflected by the values for the individual population numbers of the "transitional period" as compared to the total number of individuals. 


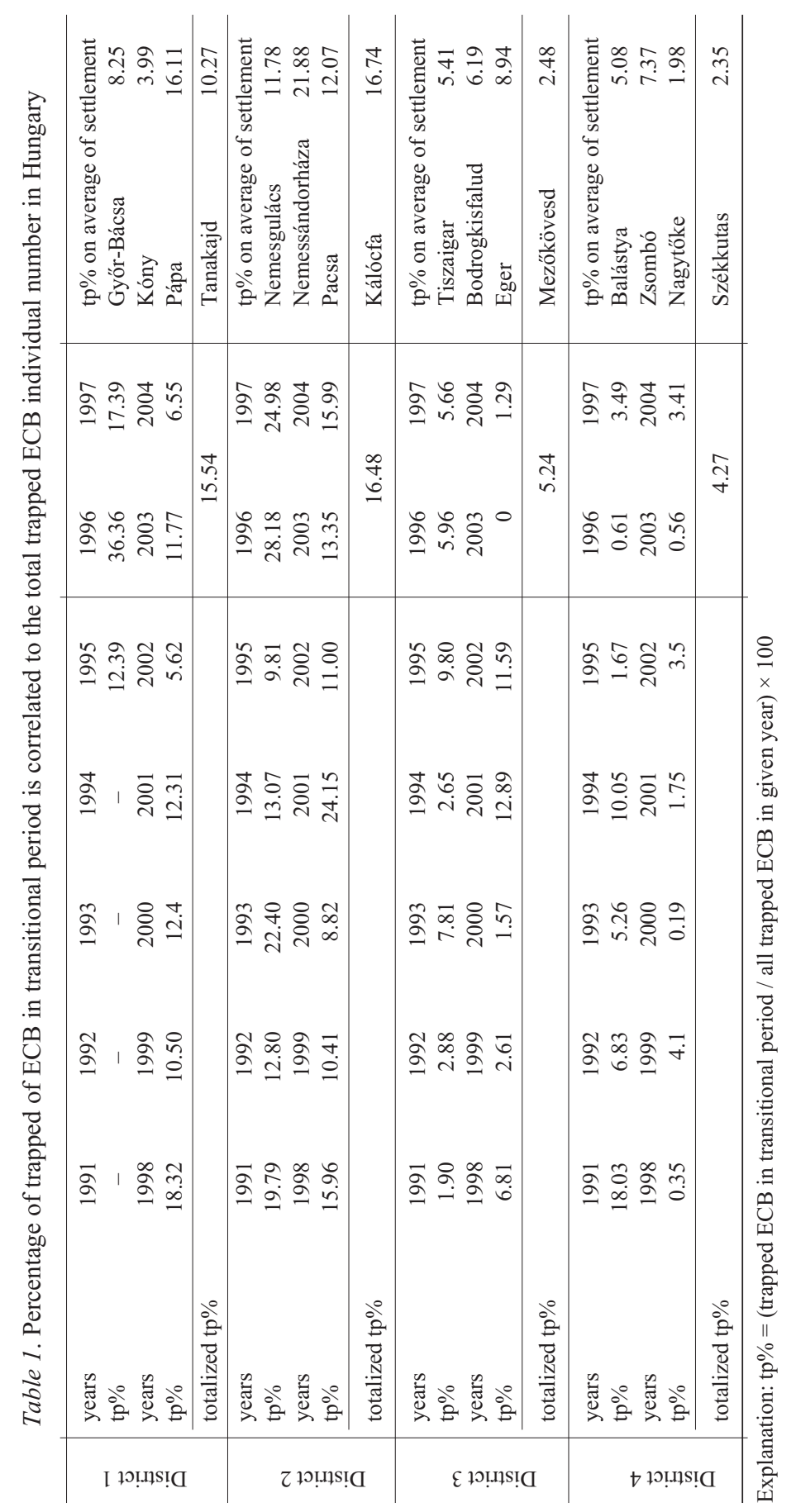

Cereal Research Communications 36, 2008 


\section{Discussion}

The "bell"-form flight pattern of the ECB unambiguously reflects the presence of the univoltine ecotype. The peaking of the single annual generation is perceptible in every case, and is marked by an introductory and descending phase, respectively, of lower individual population number. This ECB flight type was characteristic of countries to the north of Hungary, and of the northwestern region of Hungary (the tendency towards its displacement in the last years has already been proved). The "bell"-form flight pattern can be regarded as the initial phase of a subsequent change in the pattern of flight.

The displacement of the univoltine ecotype is preceeded by the appearance of the "plateau"-type flight pattern. In fact, an adult flight prolonged by climatological factors lies behind this phenomenon (Nagy and Szentkirályi 1993; Nagy et al. 1997).

The presence of the bivoltine ecotype is indicated by the appearance of the "valley"-type pattern of flight, followed after some time by the "nail"-type form. In the first case, late individuals from the first generation might well contribute to the formation of the second peak. In the case of the "nail"-type, however, with the adult flight of the summer generation, which develops without diapause, we can assume that the appearance of two peaks is due to the presence of the "true" bivoltine ecotype. Naturally, it can be imagined the less overlap of mentioned flight patterns in some areas, and the certain patterns ("plateau"- and "valley"type) can represent an overlap of univoltine and bivoltine populations, but to the verification of this statement should keep on the investigations in the future.

To recognize the appearance of the "transitional period" which separates the two peaks or two generations is important from the point of view of both entomology and actual plant protection. In the case of a low individual number trapped in midsummer following the first flight, the control in sweet corn and hybrid maize is unnecessary, pesticide treatments can be omitted, and preparations for the control of a higher individual number in the late summer flight of adults can be begun. Naturally, trap peak record, degree-day accumulation and careful scouting determining presence of potentially damaging larval populations in-field belong to the successful protection, too. In this period of time, the primary task is to reduce the number of larvae developing without diapause.

The northward expansion of the univoltine ecotype has already proved in Germany (Gathmann and Rothmeier 2005; Schmitz et al. 2002), and the same direction of expansion of the third, multivoltine ecotype of the ECB is taking place in recent decades. This may be similar to the tendency shown in Mediterranean and subtropical areas to the south of Hungary. Here too, the change of the pattern 
of flight is certainly gradual beginning with a "phenological fluctuation" of the second flight peak and ending in the development of a definite early autumn flight peak.

\section{Acknowledgements}

We are indebted to the workers of Hungarian Central Service for Plant Protection and Soil Conservation for granting access to data from the national light trap system.

\section{References}

Beck, S.D. 1983. Thermal and thermoperiodic effects on larval development and diapause in the European corn, Ostrinia nubilalis. J. Insect Physiol. 29(1):107-112.

Ellsworth, P.C., Umeozor, O.C., Kennedy, G.G., Bradley, J.R., Vanduyn, J.W. 1989. Population consequences of diapause in a model system - the European corn borer. Entomol. Exp. Appl. 53(1):45-55.

Gathmann, A., Rothmeier, I. 2005. Dispersal of the European corn borer (Ostrinia nubilalis Hbn.) in southern Rhineland - Results of the infestation assessment 2002 and 2003. J. Plant Dis. Prot. 112(2):200-203.

Jermy, T. 1988. A kártevők népességmozgalma. In: Sáringer Gy. (szerk.): Ökológia [Population dynamics of pests. Ecology (ed. by Gy. Sáringer)], Egyetemi jegyzet, Keszthely, pp. 58-80.

Lavenseau, L., Peypelut, L., Gadenne, C., Anglade, P. 1985. Environmental-factors and diapause in the European corn-borer Ostrinia nubilalis Hbn. (Lepid, Pyralidae). Evol. Zool. 110(3):275-278.

Mészáros, Z. 1969. Phenological investigations on the Hungarian population on the European corn borer (Ostrinia nubilalis Hbn.) in 1965-67. Acta Phytopath. Entomol. Hung. 4:181-185.

Nagy, B. 1961. A kukoricamoly magyarországi rajzásidejére vonatkozó újabb megfigyelések (Newer observations of European corn borer flight period in Hungary). Ann. Inst. Prot. Plant. Hung. 8:215-230.

Nagy, B., Szentkirályi, F. 1993. The life history of second flight of the European corn borer, Ostrinia nubilalis Hbn. in the Carpatian basin. Proceed. XVII. IWGO, Volos (Greece), pp. 46-52.

Nagy, B., Szentkirályi, F., Vörös, G. 1997. Changes in the pest status within maize insect assamblages in the Carpathian basin Proceed. XIX. IWGO, Guimaraes (Portugal), pp. 223-235.

Onstad, D.W., Brewer E.F. 1996. Modeling induction of diapause in North American Ostrinia nubilalis (Lepidoptera: Pyralidae) populations. Environ. Entomol. 25(5):1140-1146.

Sáringer, Gy. 1976. Diapause experiments with a population of Ostrinia nubilalis Hbn. (Lep.: Pyraustidae) in Hungary. J. Appl. Entomol. 80(4):426-434.

Schmitz, G., Rothmeier, I., Greib, G., Ross-Nickoll, M., Bartsch, D. 2002. Process and potential of the spreading of the European corn borer (Ostrinia nubilalis Hbn.) in Northwest Germany. J. Plant Dis. Prot. 109(6):624-629.

Showers, W.B., Chiang, H.J., Keaster, A.J., Hill, R.E., Reed, G.L., Sparks, A.N., Musick, G.J. 1975. Ecotypes of the European corn borer in North America. Environ. Entomol. 4:753-760.

Straub, F.B. 1977. Biológiai lexikon 3 (Encyclopedia biology). Akadémiai Kiadó, Budapest, 204 pp.

Székács, A., Fónagy, A., Fekete, G., Szentkirályi, F., Bernáth, B. 2005. Ökotoxikológiai és rovarmonitorozási vizsgálatok az agroökológia szolgálatában (Ecotoxicology and insect monitoring examinations in favour of agroecology). "Agro 21" Füzetek 37:146-159.

Cereal Research Communications 36, 2008 